\title{
当科に括ける最近 8 年間の入院患者統計
}

\author{
長谷川智彦・鈴木 八郎・稲村 博雄・原田 浩二* \\ 戸島 均*. 横山 壽一*. 原田 次郎*. 酒井 仁* \\ 布施 健生*.大木 誠*. 前山 裕之*. 奥山 孝*
}

\section{Statistics of Inpatients in Our Clinic during the Last 8 Years}

\author{
Tomohiko Hasegawa, Hachiro Suzuki and Hiroo Inamura \\ (Yamagata Prefectual Central Hospital)
}

\begin{abstract}
Koji Harada, Hitoshi Tojima, Juichi Yokoyama, Jiro Harada, Masashi Sakai, Takeo Fuse, Makoto Ohki, Hiroyuki Maeyama and Takashi Okuyama
\end{abstract}

\author{
(Yamagata University)
}

The statistics of 2,014 inpatients (1,205 males and 809 females) in Yamagata Prefectual Central Hospital, Department of Otolaryngology, between 1983 and 1990 are presented. The age distribution showed that the patients in their fifties constituted the largest group among the inpatients. The location of diseases was the nasal cavitiy and paranasal sinuses in 470 cases $(23.3 \%)$, the pharynx in 387 cases (19.2\%), the larynx in 321 cases $(15.9 \%)$, the ear in 289 cases $(14.4 \%)$, the neck in 129 cases $(6.4 \%)$, the salivary glands in 121 cases $(6.0 \%), 52$ in the oral cavity and tongue (2.6\%), the trachea and esophagus in 20 cases $(1.0 \%)$ and the other regions in 98 cases (4.9\%). The number of facial palsy was 127 (6.3\%). Since 1985, the number of inpatients has decreased, mainly because of a decreased number of inflammatory cases such as chronic sinusitis and chronic tonsillitis. There were 217 cases with malignant tumors of head and neck.

Key words: statistics, inpatient, location of disease

はじめに

山形県立中央病院耳鼻咽喉科における最近 8 年間（1983年 1月より1990年12月まで）の入院 患者の統計的観察を行ったので報告する. 今回 の統計では同一疾患による再入院を除いて, 新 入院症例だけを対象とした。

\section{結果}

1. 年度別分布

新入院患者総数 2,014 人中, 男性 1,205 人 (59.8\%)，女性809人 (40.2\%) で，男女比は $1.5: 1$ であった，年度別入院患者数は図 1 の ごとく，1984年以降減少したが，1987年以後は

\footnotetext{
山形県立中央病院耳鼻咽喉科

* 山形大学医学部耳鼻咽喉科学教室
} 
年間約 210 人前後とほぼ一定状態が続いている。

2 . 年齢別分布

年齢別入院患者数を図 2 に示す。 50 藏代が 361 人 $(17.9 \%)$ と最斗多く, 30 歳以上 60 歳未 満が $50.5 \%$ と約半数を占めていた。10藏代の及 女性が多いが，他の年铪層は男性が多かった。 80 歳以上の高秢者は31人（1.5\%）であった。

3 . 疾患部位別頻度

図 3 に各年度及び全症例に抄ける疾患部位別

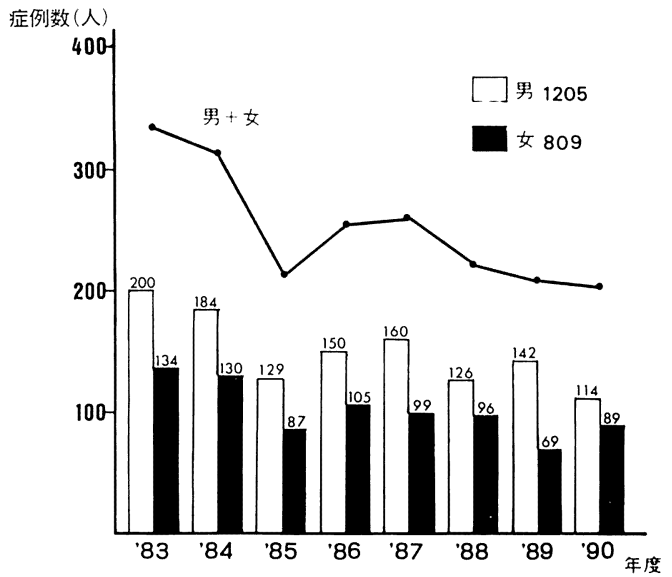

図1 年度別入院患者数
頻度を示寸。全体では鼻・副鼻腔疾患が470人 (23.3\%) と最も多く，次いで，咽頭疾患 387 人 (19.2\%)，喉頭疾患321（15.9\%)，耳疾患289 人 $(14.4 \%)$ の順であり，この 4 つ部位で 72.8 $\%$ と全体の約 $3 / 4$ を占めていた．図のごとく， 年度により多少のばらつきを認めるが，近年， 鼻・副鼻腔疾患と咽頭疾患が減少している傾向 に荔った。他の部位の疾患に関しては大きな変

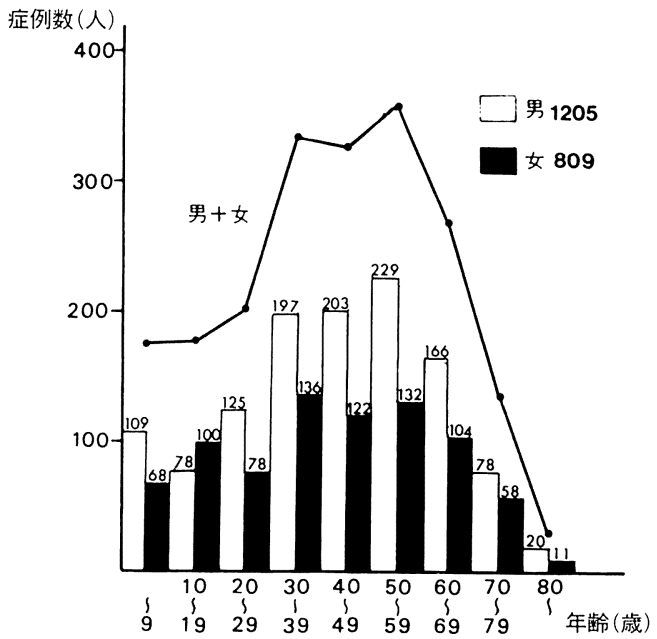

図 2 个洲命別入院患者数

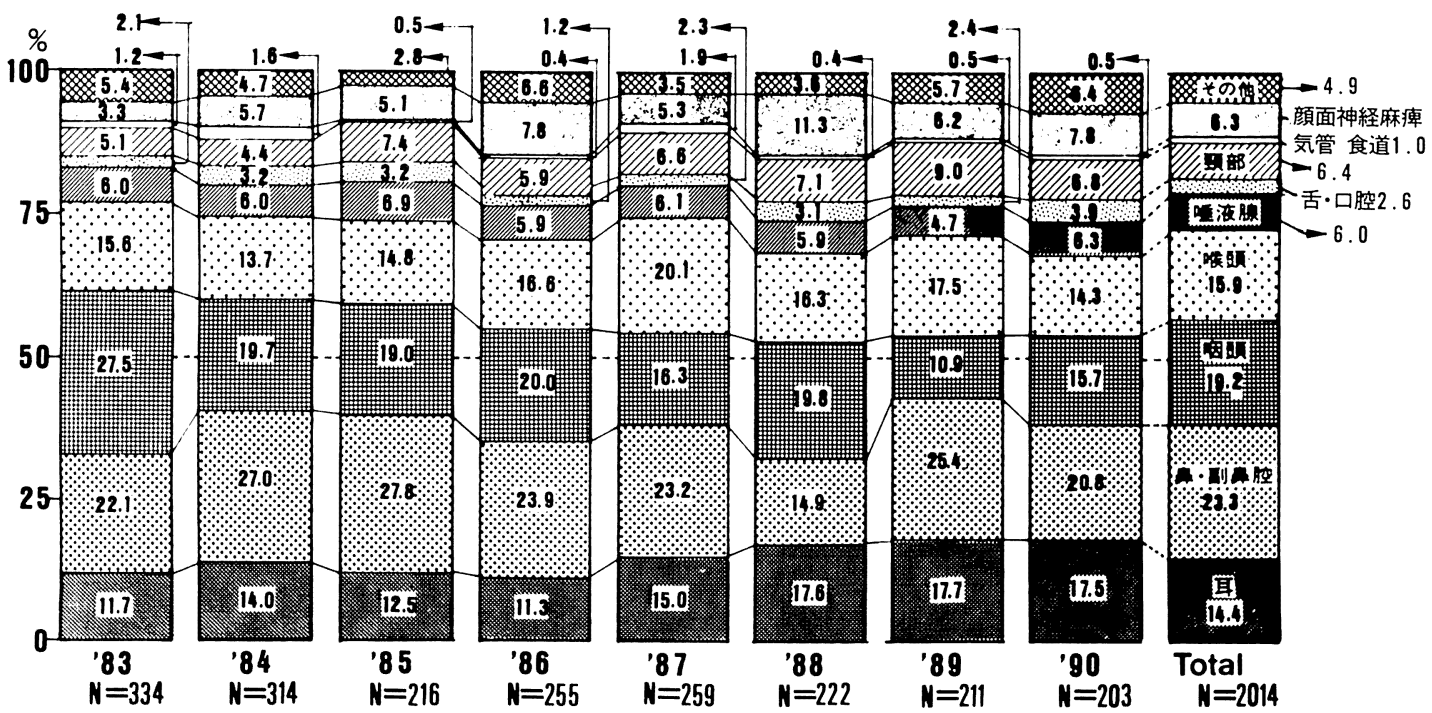

図 3 疾患部位别频度 
化はなかった。

4. 各部位に抢ける年齢分布と疾患及び手術 頻度

1) 耳疾患

年齢分布では， 10 藏未満が57人 (19.7\%) と 最も多く, 次いで30歳代 (16.3\%), 10歳代 (15.9 \%) の順で男女比は注注1：1であった（図4 左)。耳疾患 289 人の内訳は, 慢性中耳炎を主と した炎症が97人 (33.6\%) と最多で，以下真珠 腫, 突発性難聴, 先天性耳瘦孔, メ二エール病, 外傷の順であった（図 4 右上）。耳疾患の手術 件数は218件で，鼓室形成術が98件（45.0\%） と最も多く, 次いで中耳根本手術, 耳㾇孔摘出 術, 中耳腔内チューブ留置術の順であった（図 4 右下).

2 ) 鼻・副鼻腔疾患

50 歳代が 110 人 $(23.4 \%)$ とピークを示し, 30歳 以上 70 歳未満が $77.7 \%$ と約 $3 / 4$ を占め, 男女比 は2.1：1であった（図 5 左）。鼻・副鼻腔疾患 470 人の疾患別内訳は，慢性副鼻腔炎を主とす る炎症が 241 人 $(51.2 \%)$ と約半数を占めてい

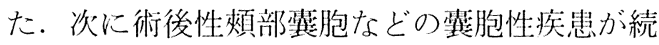
き, 以下鼻出血, 腫瘍の順であった(四う右上).

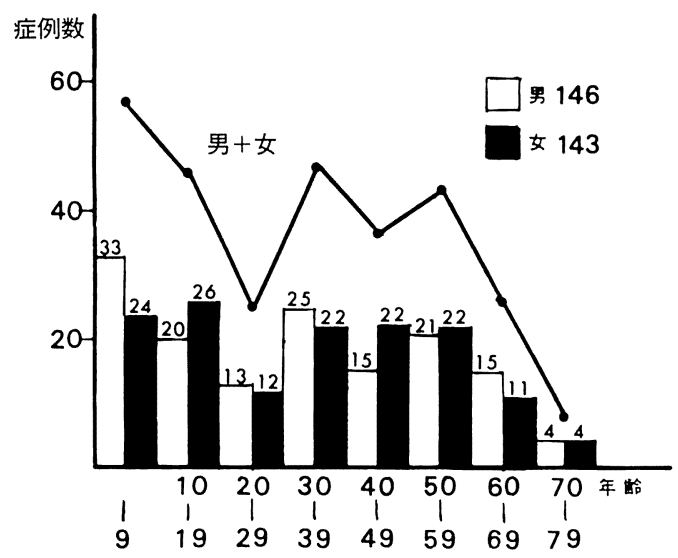

手術件数は571件で, 症例数よりもかなり多く なっているが，これは雨側性に手術を行った場 合, 鼻内手術以外は左右各々 1 件として算定し たためと，覀性腫瘍の中には数回にわたって手 術をした例があるためである，上顎洞穊骨洞根 本手術232件（40.6\%）と最も多く，次いで節 骨洞鼻内手術, 悪性腫瘍の手術の順であった（四 5 右下).

\section{3 ）咽頭疾患}

10 歳未満と 20 歳代にピークがあり，各々 80 人 （20.7\%）であった，次いで30歳代，10歳代の 順であり，40歳未満が $77.3 \%$ と $3 / 4$ 以上を占め， 男女比は，1.9：1であった（図 6 左）。咽頭疾 患387人の内訳は, 慢性扁桃炎とアデノイド増 殖症を主とする炎症が 334 人 (86.3\%) で大部 分を占め，次に腫瘍48人 (12.4\%) の順であっ た (図 6 右上). 手術件数363件中, 口蓋扁桃摘 出術とアデノイド切除術が344件（94.7\%）と そのほとんどを占めていた（図 6 右下）。

4 ) 喉頭疾患

年齢分布をみると，全体的には40歳代から50 藏代にピークがあり，男性のピークが50歳代に あるのに比べ，女性のピークは30嘁代にあった。

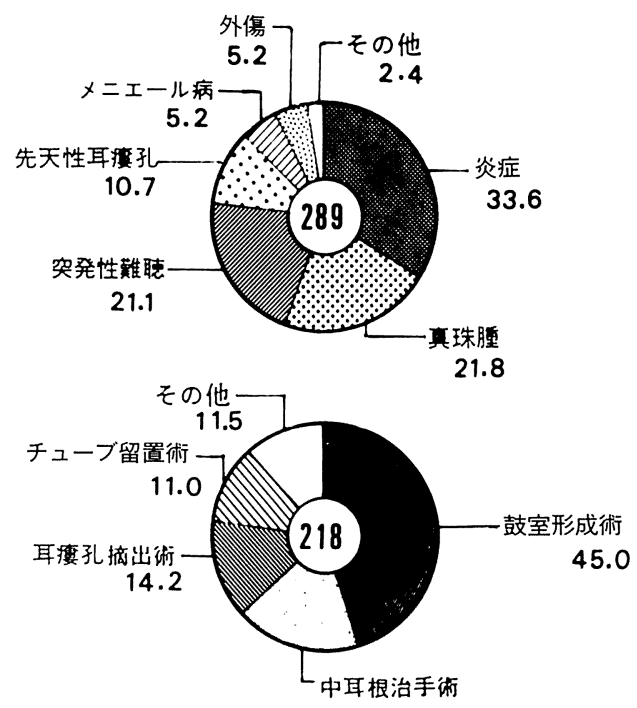

18.3

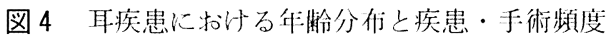


男女比は2.2：1 であった（図 7 左）。喉頭疾患 321 人の疾患別内訳は, 晚頭ポリープ（ポリー プ様変性を含む）が201人（62.6\%）と最多で， 次いで腫瘍75人 (23.4\%), 炎症の順であった

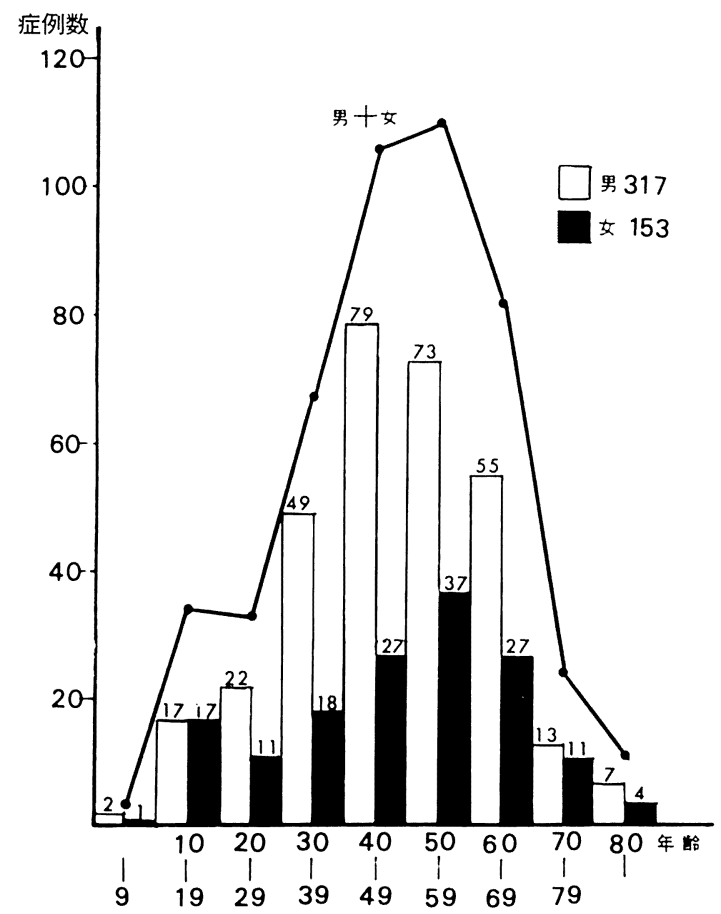

(図 7 右上). 喉頭疾患の手術件数は284件で, 顕微鏡下喉頭手術が262件を古め，その内39件 (13.7\%) が悪性腫晹の手術であった。次いで 晚頭全摘術が18件 (6.4\%) であった（図 7 右
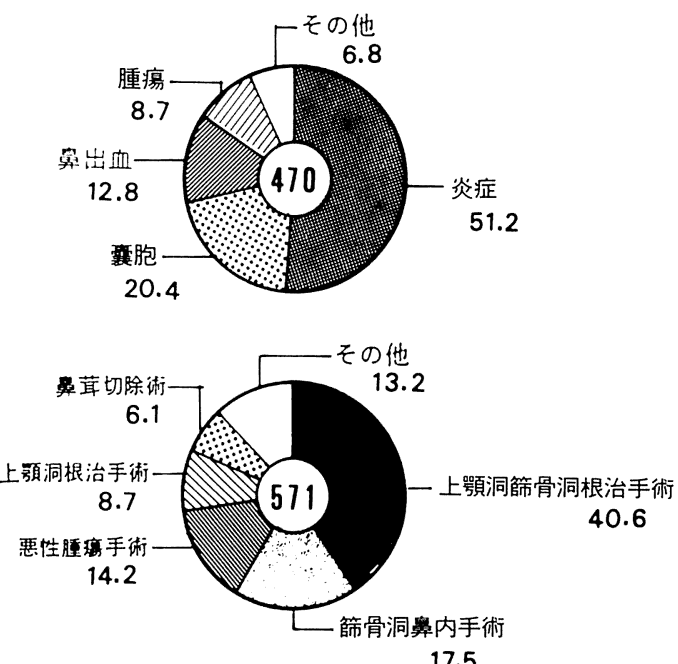

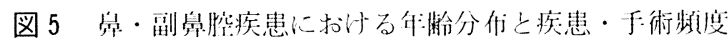
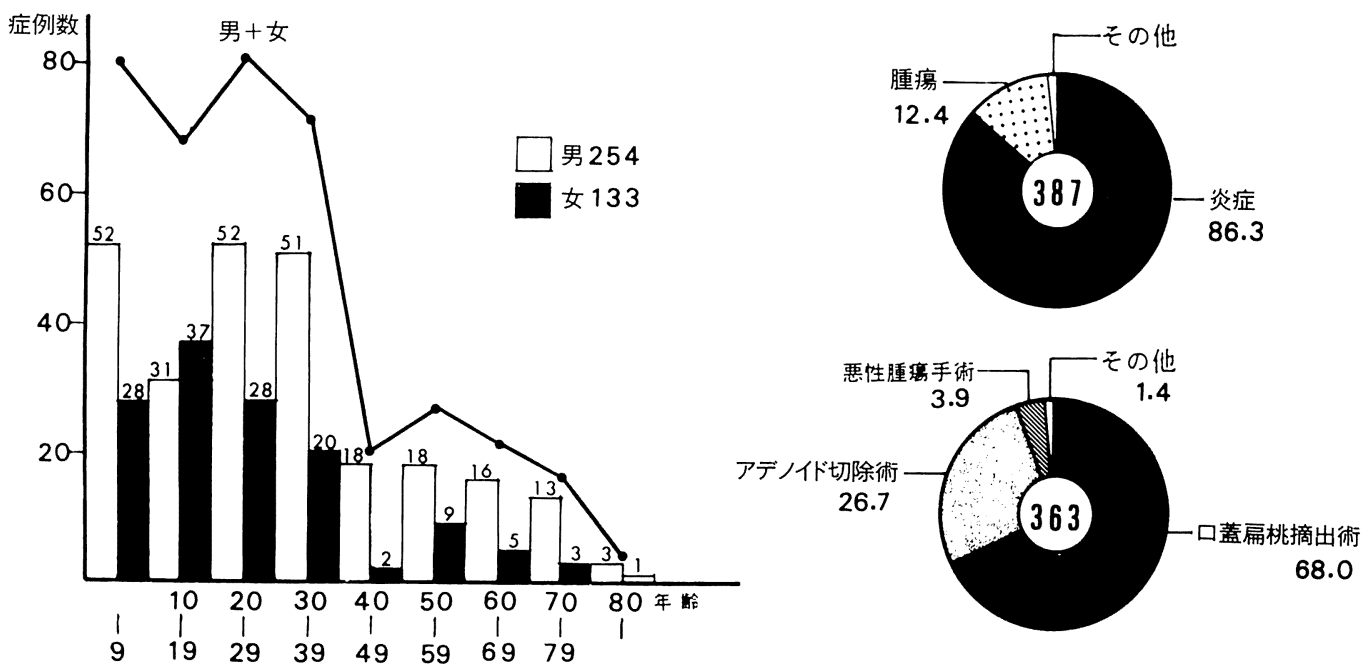

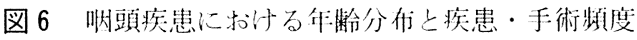


下).

\section{5）㕰液腺疾患}

20藏代から40歳代に患者が集中しており，こ の年代層で 67 人 $(55.4 \%)$ であった。男女比は ほぼ1：1であったが，20歳末満及び60藏以上 では女性に多い傾向を示した（図８左）。唾液 腺疾患 121 人の疾患别内訳は, 腫瘍が 64 人 (52.9\%) と最多で，次いで炎症41人 $(33.9 \%)$,
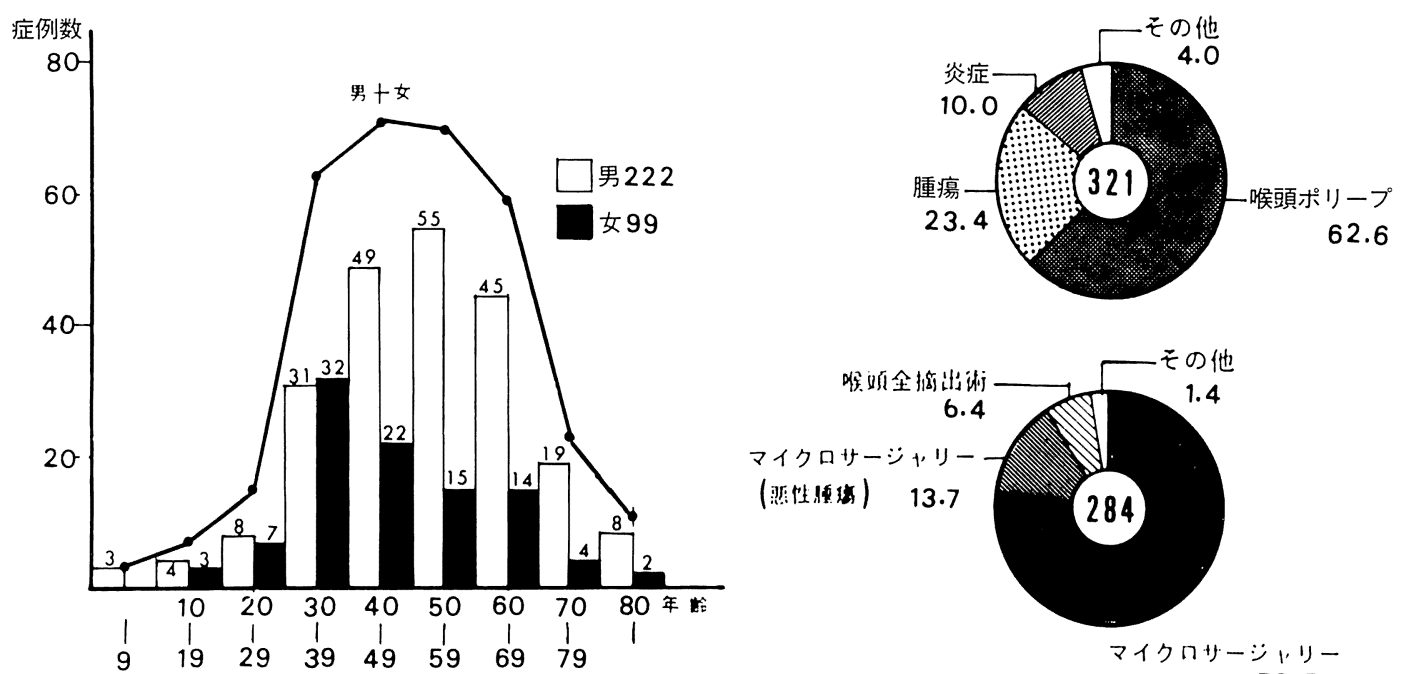

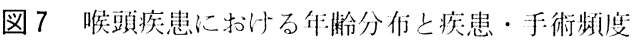
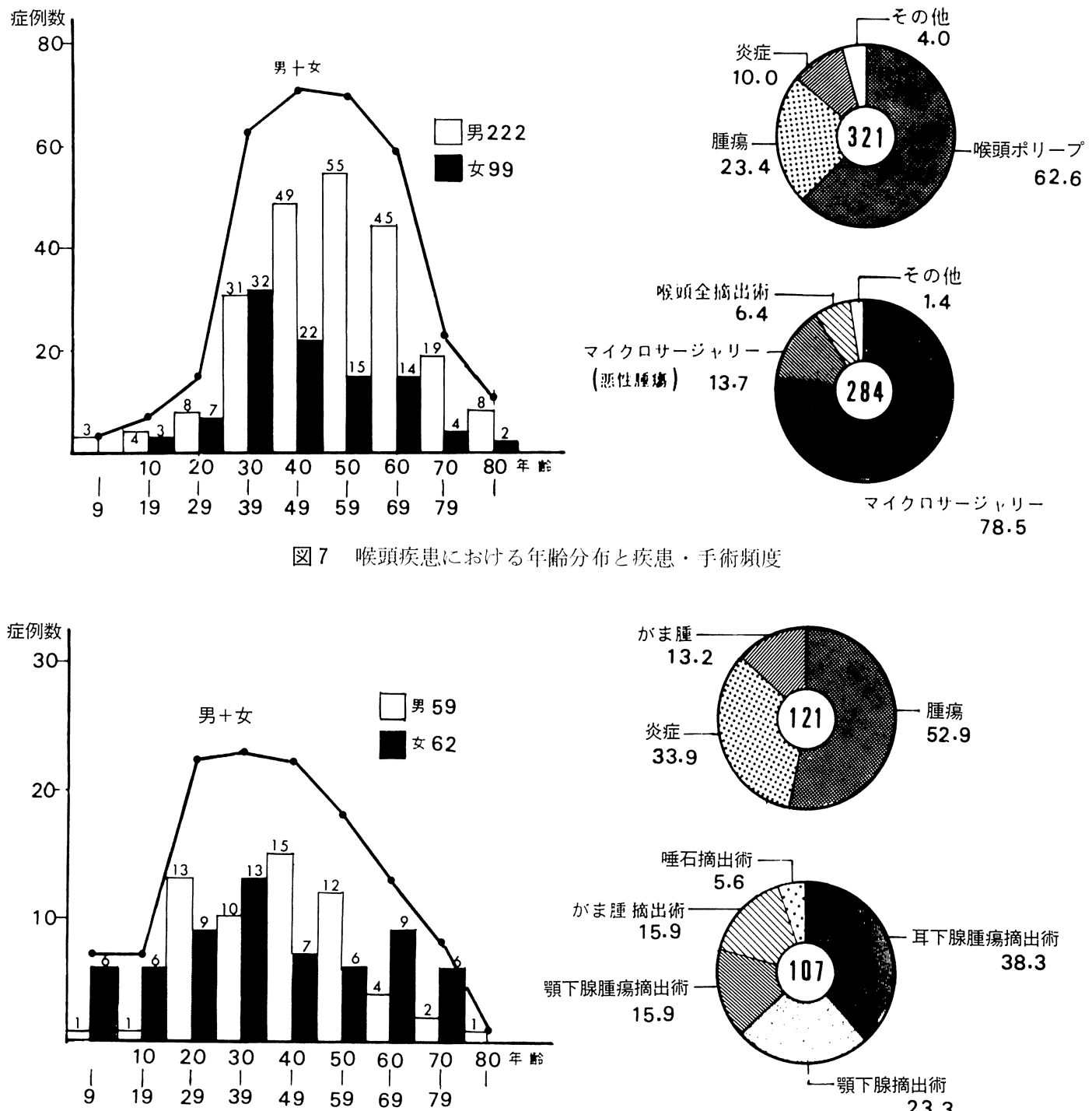

78.5
ガマ腫16人 (13.2\%)の順であった（困 8 右上). 手術件数は107件で, 耳下腺腫瘍摘出術が 41 件 (38.3\%) を占め，次いで顎下腺摘出術が26件 $(24.3 \%)$ ，顎下腺腫瘍摘出術とガマ腫摘出術が 各々 17 件: $(15.9 \%)$ ，棰石摘出術 6 件（5.6\%) であった（戍８右下）。

6) 舌・ 口腔疾患

70 歳以上が 17 人 $(32.7 \%)$ と最多で, 次いで50

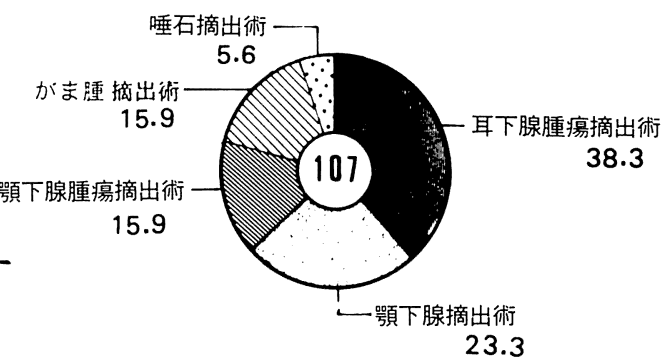

図 8 唾液線疾患にお方年粭分布と疾患・手術频度 
歳代と60歳代が各11人（21.1\%）で，50歳以上 が39人（74.9\%）と約 3/4を占めていた．男女 比は1.7：1であった（図 9 左）。舌・口腔疾患 52 人の内訳は腫瘍が 37 人 $(71.2 \%)$ と最多で, 次いで炎症 7 人 $(13.5 \%)$, 外傷 5 人 $(9.6 \%)$ であった（図 9 右上）。手術件数は53件で，悪 性腫瘍手術が30件（56.6\%）を占め，次いで良 性腫瘍摘出術が15件（28.3）であった（図９右
下).

\section{7 ) 頸部 - 甲状腺疾患}

年龄分布は50歳代が 27 人（20.9\%） と最も多 く, 次いで40歳代 26 人 $(20.2 \%) ， 30$ 歳代 22 人 (17.0\%)，60歳代20人（15.5\%）で，男女比は 1：1.5 と女性が多かった（図10左）。頸部・甲 状腺疾患 129 人の内訳は，腫瘍が 82 人 (63.6\%) と最多で，次いで炎症と暻胞が各々 23 人 (17.8
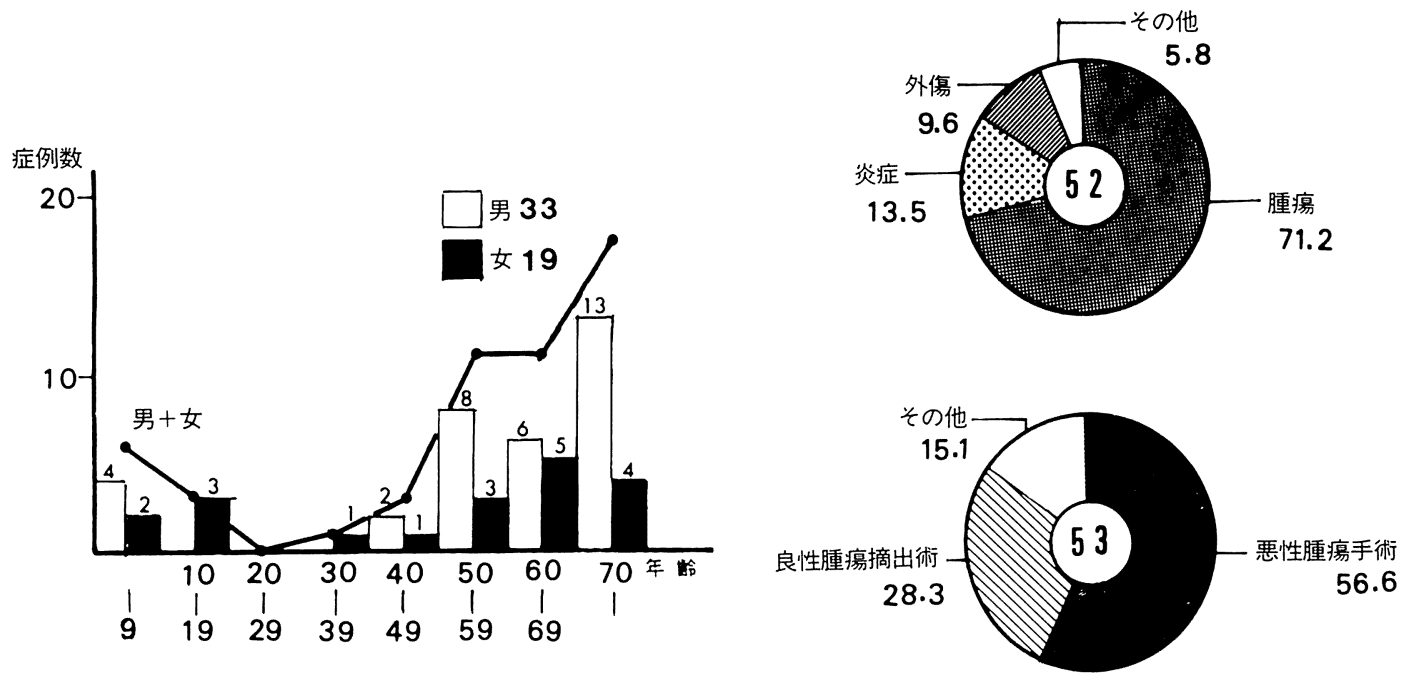

図 9 舌・日腔疾患に拈訬る年粭分布と疾患・手術頻度
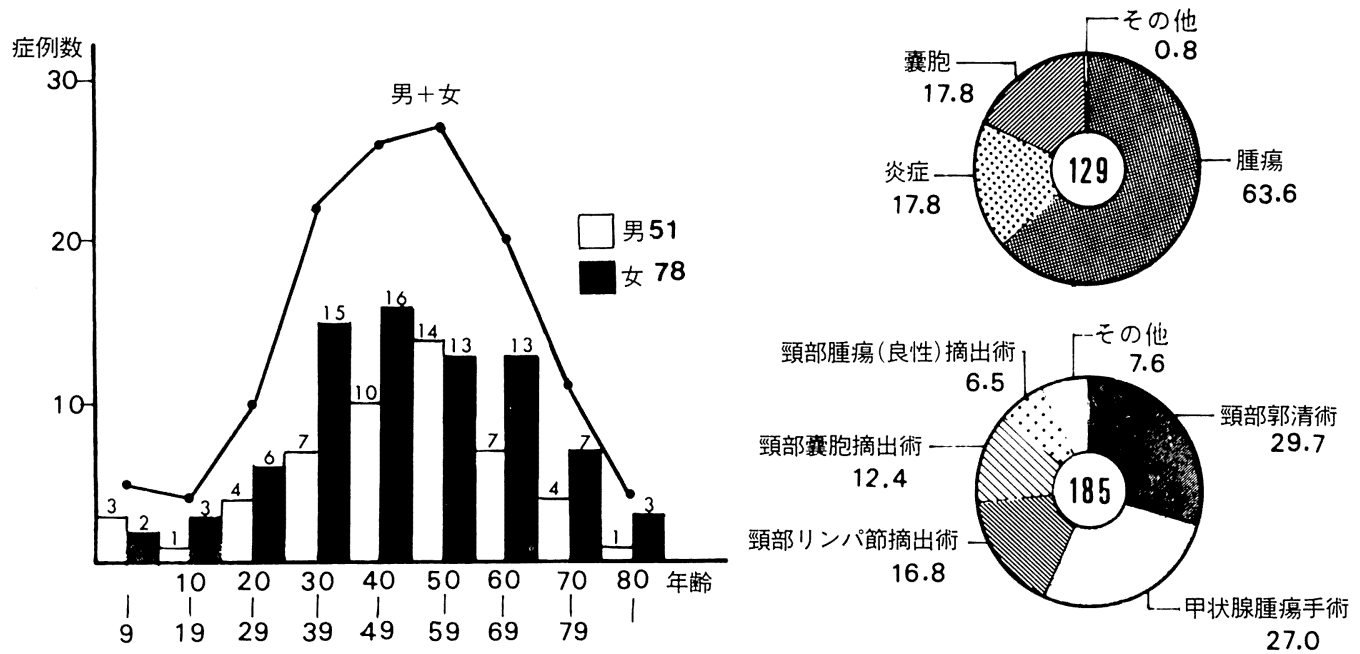

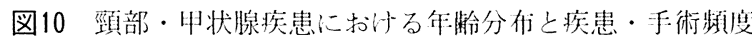


\%)であった（図10右上）。手術件数は185件で 疾患数を大きく上回っているが，これは他部位 の悪性腫場に対して行った頸部郭清術や頸部り ンパ節摘出術が含まれているためである。頸部 郭清術が55件 $(29.7 \%)$ ，柙状腺腫瘍手術が50 件 $(27.0 \%)$ ，頸部リンパ節摘出術31件（16.8

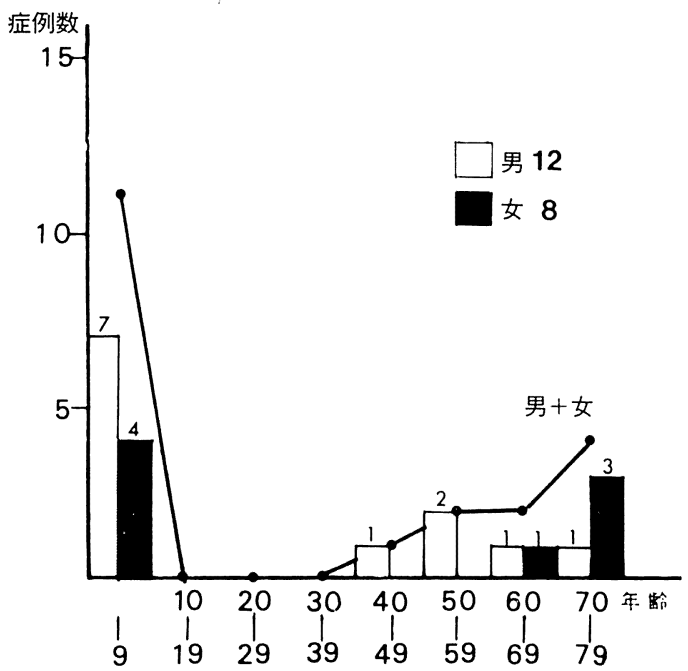

\%)，囊胞摘出術23件（12.4\%)，良性腫瘍摘出 術12件（6.5\%）であった（図10右下).

8 ）気管・食道

年齢分布 的に多く，次いで70歳代 4 人 (20.0\%) で，男 女比は1.5：1であった (図11左)。疾患別内訳
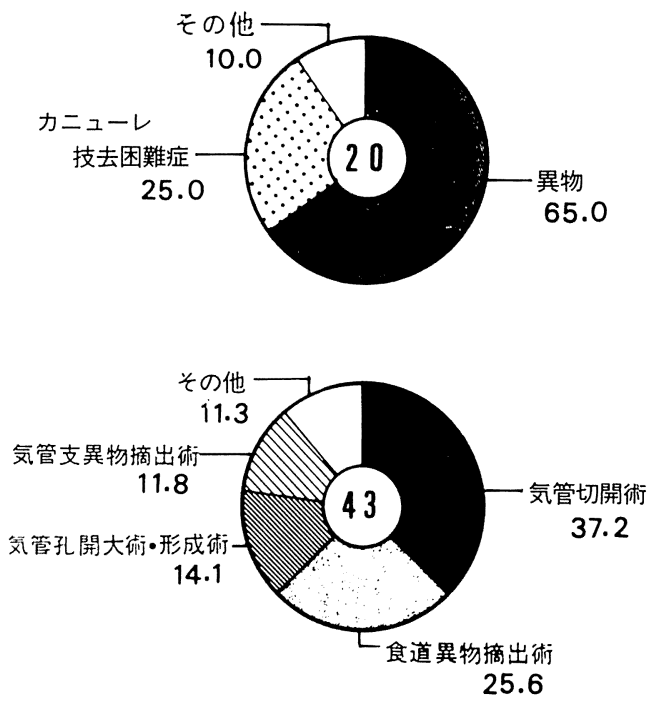

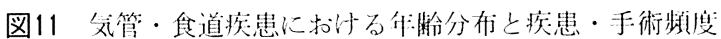
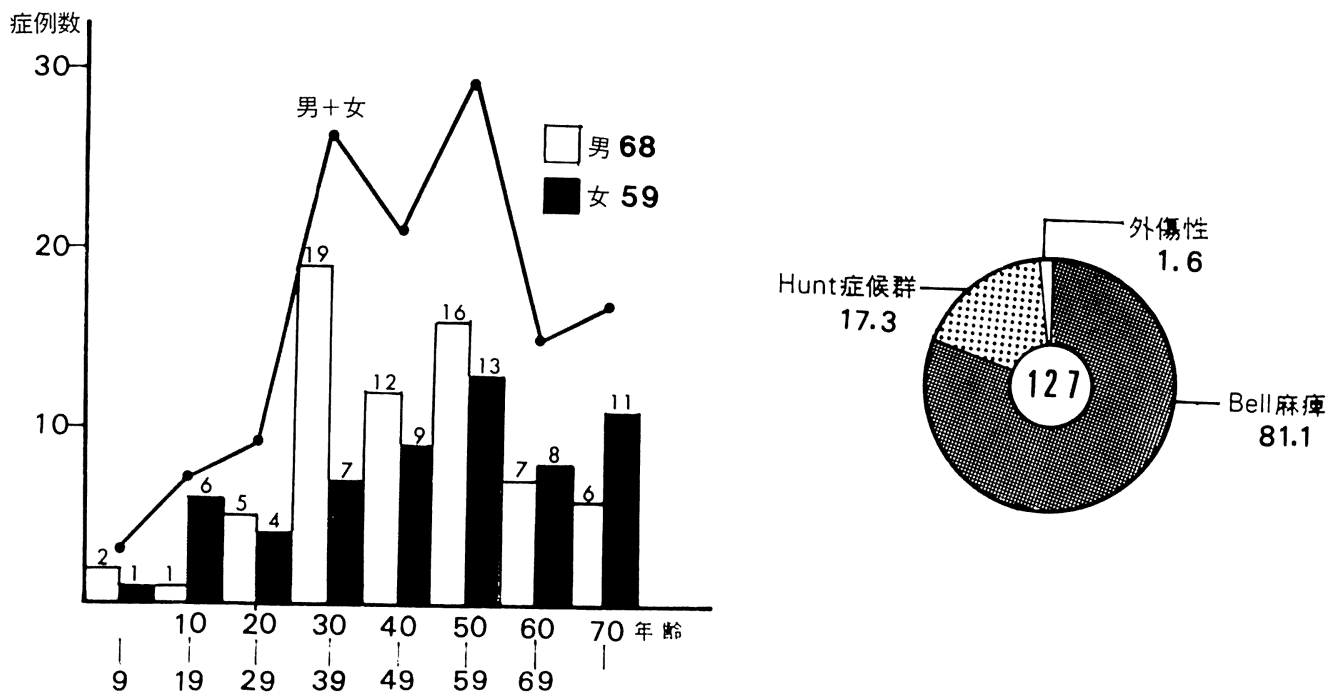

図12 顔面神経林琕に拈け万年秢分布と疾患頉度 
は, 異物が 13 人 (65.0\%) と最多で, 次いでカ ニューレ抜去困難症 5 人 (25.0\%) であった（図 11右上). 手術件数は 43 件で, 気管切開術 16 件 (37.2\%)，食道異物摘出術11件 $(25.6 \%)$ ，力 二 $\_$-レ抜去困難症に対する肉芽除去術や気管 孔開大術 6 件 (14.1\%), 気管支異物摘出術 5 件（11.8\%）であった（図11右下)。ここに示 寸気管切開術の件数は当科入院患者中で，呼吸 管理の必要上行った件数だけを示したもので, 他科よりの依頼で行ったものは含まれていない.

9 ) 顔面神経麻痺

50 歳代が 29 人 $(22.8 \%)$ と最も多く, 次いで30 歳代 26 人 $(20.5 \%) ， 40$ 歳代 21 人 $(16.5 \%)$ の 順で男女比は1.2：1であった（図12左）。顔面 神経麻痄 127 人の内訳はベル麻疸が 103 人（81.1 $\%$ ）八ント症候群 22 人 $(17.3 \%)$, 外傷性 2 人 (1.6\%) であった（図12右上）。

10）その他

上記疾患部位に含まれないその他の疾患は98 人で，その内訳は耳性以外のめまいが85人 (86.7\%) と圧倒的多数を占め，40歳代から60 歳代の女性に多かった。他は頭部・顔面外傷,

多発性神経炎などであった。

5 . 悪性腫瘍

この期間の悪性腫瘍患者数は 217 人で，全入 院患者数の $10.8 \%$ を占めていた，その部位別内 訳を図13に示す.多い順に，喉頭75人 (34.6\%), 咽頭 37 人 $(17.1 \%)$, 鼻 - 副鼻腔 30 人 $(13.8 \%)$, 頸部・甲状腺 25 人 $(11.5 \%)$, 舌・口腔 22 人

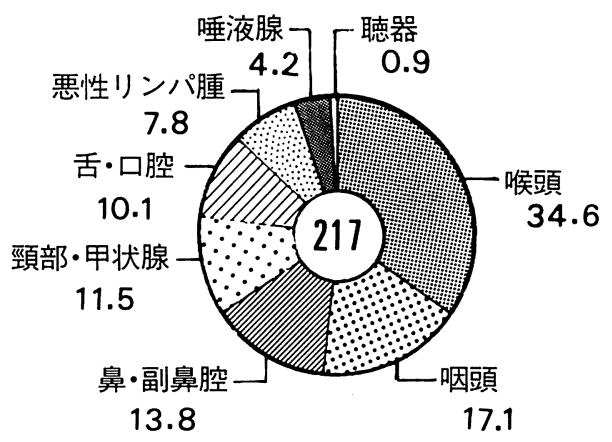

図13 悪性腫瘍部位別頻度
$(10.1 \%)$, 悪性リンパ腫17人 $(7.8 \%)$, 唾液腺 9 人 $(4.2 \%)$, 耳 2 人 $(0.9 \%)$ であった。平 均年齢は63.5歳で, 70 歳代が 49 人 $(22.6 \%), 80$ 歳 以上が21人 $(9.7 \%)$ であった。

\section{考察}

1983年より1990年までの 8 年間の新規入院患 者 2,014 人について統計的観察を行い，入院患 者動態を検討した。

1984年を境にして入院患者数が減少している が，この要因としては，他施設でも報告1) 31 さ れているよらに，慢性副鼻腔炎と慢性扁桃炎患 者の絶対数の減少が考えられる，さらに，1984 年前後に当院の診療圏内における他施設におい て，耳鼻咽喉科が開設されたり人員増加補強な どが行われたため，慢性副鼻腔炎や慢性扁桃炎 などの炎症性疾患は，多数の施設に分散してい る可能性が高く，患者数が相対的に減少してい るとも考えられる.

入院患者の男女比は1.5:1 で他施設の報告 とほぼ一致していた．年龄別分布をみると，10 墄未満が他施設に比べ少ない傾向にあったが, 当院では頭頸部領域の先天性奇形などは形成外 科で加療しているためと考えられる.

疾患部位別でみるといくつかの特徴が認めら れた。喉頭疾患の年齢分布をみると，30歳代ま では男女差が認められないが，40歳代以上では 男性の占める割合が圧倒的に多くなっている.

これは喉頭覀性腫瘍が60歳代から70歳代の男性 に压倒的に多いためと考兄られる. 舌・口腔疾 患の年齢分布をみると, 50 歳以上が約 $3 / 4$ を占 め, 70歳代にピークがあり, かなり偏った分布 を示している.これはこの領域で入院対象とな る疾患の大部分が腫瘍性病変で, しかも悪性腫 瘍の占める割合が高いためと考兄られる。頸部

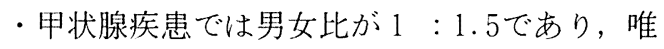
一女性が多かった。これは甲状腺腫瘍が女性に 多いためと思われる. 気管・食道疾患でも特徵 的な年齢分布を示していた。すなわち，10歳未 満(厳密には 2 歳以下) と70歳以上の 2 つにピー クを示した。この領域の入院対象疾患の大部分 
が異物症であり, 気管支異物は 1 歳前後に集中 し，食道異物は幼児と高龃者に多いためと考え られる。

我が国の高齢化社会を反映するかのように， 頭頸部悪性腫瘍患者の高齢化現象が報告されて (る ${ }^{4) 5)}$. 当科での最近 8 年間の頭頸部悪性腫 瘍患者 217 人の平均年齢は 63.5 歳で， 70 歳代が 49 人 $(22.6 \%) ， 80$ 歳以上が 21 人 $(9.7 \%)$ であ った．以前の当科の報告67) に上れば，喉頭癌 及び副鼻腔癌いずれにおいても，70歳以上が 37 〜38\%を占め， 5 年前にすでに高齢化が認めら れていた．最近では平均年齢には大きな変動は ないが，80歳以上の高齢者が増加傾向にあり， しかもこの年代層の予後が悪い事より，今後益 々高齢化社会が進めば，頭頸部悪性腫瘍の治療 や予後に影響を与えることが示唆された。

\section{まとめ}

最近 8 年間の入院患者の 2,014 人の統計的観 察を行った結果，以下の結論を得た。

1 ）男女比は1.5：1 で男性に多く，50歳代 にピークを認めた。

2 ）入院患者数の減少を認めるが, 慢性副鼻 腔炎之慢性扁桃炎の減少が原因と考えられた。

3 ) 疾患部位別頻度は, 鼻・副鼻腔 $(23.3 \%)$, 咽頭 (19.2\%), 喉頭 (15.9\%), 耳 (14.4\%), 頸部 - 甲状腺 $(6.4 \%)$, 顔面神経麻痺 $(6.3 \%)$, 唾液腺 $(6.0 \%)$, 舌 - 口腔 $(2.6 \%)$, 気管・食 道（1.0\%）の順に多かった。

4 ）頭頸部悪性腫瘍患者は217人で, 喉頭
(34.6\%)，咽頭 (17.1\%)，鼻・副鼻腔（13.8 $\%)$, 頸部 - 甲状腺 $(11.5 \%)$, 舌 - 口腔 (10.1 $\%)$, 悪性リンパ腫 $(7.8 \%)$, 唾液腺 $(4.2 \%)$, 聴器 $(0.9 \%)$ であった。平均年跘は63.5歳で, 70 歳代が 49 人 $(22.6 \%), 80$ 歳以上が 21 人 $(9.7$ \%）であった.

\section{文献}

1）仲神久つ子, 藤林慶子, 堀 瑞代, 他：当科に お外る最近 5 年間の入院患者の統計的観察. 耳 鼻臨床 $78: 1334 \sim 1340,1985$.

2）竹内和郎，大梘好正，大谷 㦑：当教室 28 年間 の入院患者統計.耳鼻臨床 $78 ： 999 \sim 1007,1985$.

3）志賀伸之, 小林俊光, 高坂知節 : 東北大学耳鼻 咽喉科に扑ける入院患者統計とその推理. 耳鼻 臨床 $80 ： 1719 \sim 1728,1987$.

4）宮崎 洋, 松村祐二郎, 野村 和, 他: 高柃頭 頸部癌患者の動向とその取り扱いについて一そ の 1. 手術を中心に一. 耳鼻 $83: 51 \sim 55,1987$.

5）佐藤武男 : 喉頭癌一その基礎と臨床一第 2 版. 22 29頁，金原出版，東京， 1986.

6）戸島 均, 鈴木八郎, 大竹欣哉: 副鼻腔癌, 過 去10年の治療成績，山形県病医誌 $18: 30 \sim 34$, 1984.

7）長谷川智彦，鈴木八郎，大竹欣哉：喉頭癌の治 療成績一最近 10 年間の61症例について一. 山形 県病医誌 $19: 193 \sim 197,1985$.

(別刷請求先：長谷川智彦 干990-23 山形市桜町7-17 山形県立中央病院耳鼻咽喉科 